Research Article

\title{
The Role of Matrix Metalloproteinase-2 (MMP-2) in Serum and Peritoneal Fluid of Endometriotic Patients
}

\author{
Peran Matriks Metalloproteinase-2 (MMP-2) Serum dan \\ Cairan Peritoneum pada Pasien Endometriosis
}

\author{
Nurledil Baharuddin, Nusratuddin Abdullah, Telly Tessy, St Maisuri T Chalid \\ Department of Obstetrics and Gynecology \\ Faculty of Medicine Universitas Hasanuddin/ \\ Dr. Wahidin Sudirohusodo Hospital \\ Makassar
}

\begin{abstract}
Objective: To determine the role of matrix metalloproteinase-2 (MMP-2) in serum and peritoneal fluid of endometriotic patients.

Methods: Research's design using cross-sectional method in Dr. Wahidin Sudirohusodo hospital and several other hospitals in Makassar within May 2015 until May 2016. Subjects were chosen using consecutive sampling technique. The examination using the ELISA method. The data were analysed using Fisher exact, t-independent, Mann-Whitney, and Spearman association.

Results: A total of 50 subjects were recruited in this study. Mostly the value of MMP-2 serum and peritoneal fluid in endometriosis group was higher compare to study control. There was significant different between the total of MMP-2 serum and peritoneal fluid. There was also a significant association between the value of MMP-2 serum and peritoneal fluid with endometriosis.

Conclusion: The value of MMP-2 serum and peritoneal fluid were higher in endometriotic patients compared to those without endometriosis. The higher the value of MMP-2 serum and peritoneal fluid, the higher the stage of endometriosis.

[Indones J Obstet Gynecol 2018; 6-2: 104-109]
\end{abstract}

Keywords: endometriosis, matrix metalloproteinase-2, MMP-2

\begin{abstract}
Abstrak
Tujuan: Menentukan peran matriks metalloproteinase-2 (MMP2) pada serum dan cairan peritoneum pasien endometriosis.

Metode: Desain penelitan dengan metode potong lintang dilakukan di RS Dr. Wahidin Sudirohusodo dan jejaringnya di Makassar pada Mei 2015 sampai Mei 2016. Pemilihan subjek melalui teknik consecutive sampling. Pemeriksaan menggunakan metode ELISA. Analisis data menggunakan uji statistik Fisher exact, $t$ independen, Mann-Whitney, dan uji korelasi Spearman.

Hasil: Sejumlah 50 subjek direkrut pada studi ini. Rerata kadar MMP-2 serum dan cairan peritoneum kelompok endometriosis lebih tinggi dibandingkan kontrol $(p<0,05)$. Terdapat perbedaan bermakna rerata antara kadar MMP-2 serum stadium III-IV dengan stadium I-II tetapi pada cairan peritoneum tidak bermakna. Kadar MMP-2 serum dan cairan peritoneum berkorelasi signifikan dengan kejadian endometriosis.

Kesimpulan: Kadar MMP-2 serum dan cairan peritoneum lebih tinggi pada pasien endometriosis dibandingkan dengan pasien tanpa endometriosis. Semakin tinggi kadar MMP-2 serum dan cairan endometrium, semakin berat pula derajat endometriosis.

[Maj Obstet Ginekol Indones 2018; 6-2: 104-109]
\end{abstract}

Kata kunci: endometriosis, matrix metalloproteinase-2, MMP-2

Correspondence: NurIedil Baharuddin.: nuriedil@yahoo.co.id

\section{INTRODUCTION}

Endometriosis is a benign gynecological disorder characterised by the presence of endometrial glands and stroma cells that grows outside the uterine cavity and is associated with pelvic pain and infertility. Ectopic endometrial tissue normally found in the pelvic cavity, but can also exist in all parts of the body. Signs and symptoms of endometriosis vary, tend to be progressive and recurrent and often creates difficulties for women and doctors. ${ }^{1}$

Until now, the aetiology and pathogenesis of endometriosis are not known with certainty.
Endometriosis is found in about $3-10 \%$ of the female population of reproductive age. The incidence of endometriosis in women with dysmenorrheal is $60-80 \%, 30-50 \%$ of women with complaints of abdominal pain, and 30-40 women with infertility. This incidence is high enough to put endometriosis as one of the main reproductive problems nowaday. Additionally, the pathophysiology and the impact of clinical disorders caused by endometriosis and its management is still not as expected. ${ }^{2}$ There is $63.6 \%$ incidence of endometriosis of infertility cases. At the Dr. Soetomo General Hospital obtained a trend of increased incidence of 
endometriosis with $23 \%$ in $1980,37 \%$ in 1990 and reached $50 \%$ in $2002 .^{3}$

The cause of endometriosis has yet known with certainty. There are several theories put forward about the cause of endometriosis, one of the most common theories of the cause of endometriosis is regurgitation of menstrual blood, which allows the deployment of endometrial cells into the peritoneal cavity. Peritoneal endometriosis, which is the most common form of endometriosis occurs due to increase of metalloproteinases lesions. Red endometriosis is the most active type of endometriosis. In this type, there is increasing activity of angiogenesis which result in increase of blood flow in the endometriosis lesions. It also explains the high incidence of menstrual pain. Macrophages and other immuno competent cells surrounding the endometriosis lesions and issuing various types of cytokines catabolic intended to cause chronic inflammatory reactions and stimulate the formation of fibrotic tissue. ${ }^{4}$

The process of angiogenesis in excess endometrial tissue suspected as an important mechanism in the pathogenesis of endometriosis. The process of angiogenesis in addition to a role in the onset of endometriosis also plays a role in implantation, tissue remodeling and the process of metastasis. ${ }^{2}$ Lately, research on endometriosis involving elements of peritoneal fluid and the process of angiogenesis open many new horizons of the pathogenesis of endometriosis, where the involvement of autocrine and paracrine factors thought to play a major role. ${ }^{5}$

In addition to VEGF, transforming growth factor-beta 1 (TGF- $\beta 1$ ) and soluble endoglin; matrix metalloproteinase (MMP) is also widely studied as an angiogenesis factor in the occurrence of endometriosis. In a normal menstrual cycle, i.e. the inhibitors of MMPs and tissue inhibitors of matrix metalloproteinases (TIMPs), play a significant role in the remodelling of the endometrial tissue. MMP also plays an important role in physiological and pathological processes in humans which are embryogenesis, angiogenesis, wound healing and metastases. ${ }^{6}$

A previous study by Salata, suggests the approximate concentration of serum MMP-2, MMP-9, TIMP-1 and TIMP-2 did not reflect the severity of endometriosis, although MMP activity increased in the peritoneal fluid of women with endometriosis. $^{7}$
Further research by Weigel et al., reported there is a difference between MMP-2, MMP-9 and PCNA in stages of endometriosis and endometrial cancer. ${ }^{8}$ Research by Jana et al. found MMP-2 plays an important role in pathological angiogenesis, and an imbalance ratio of MMP- 2 and TIMP- 2 are thought to modulate angiogenesis during the early development of endometriosis. These markers may assist in the evaluation of aggressiveness and invasive ability of endometriosis at different locations. The results obtained could explain the pathogenesis of endometriosis and the development of endometriosis therapy. ${ }^{9}$

Research on the role of MMP-2 as a marker of angiogenesis in endometriosis using serum and peritoneal fluid has never yet been studied in South Sulawesi. Therefore, the authors are interested in conducting research that aims to determine the relationship between levels of MMP-2 in serum and peritoneal fluid and the development of endometriosis.

\section{METHOD}

The study was conducted at Dr. Wahidin Sudirohusodo Hospital, Makassar and other networking Hospitals Department of Obstetrics and Gynecology, Faculty of Medicine, Universitas Hasanuddin in Makassar began in May 2015 until May 2016.

The method used is observational with a crosssectional design. The study population was all patients who underwent laparoscopic in Dr. Wahidin Sudirohusodo Hospital, Makassar and other networking Hospitals Department of Obstetrics and Gynecology, Faculty of Medicine, Universitas Hasanuddin in Makassar. Samples are all patients with endometriosis that underwent laparoscopic with various operating indications that met the inclusion criteria and had signed a letter of approval. The sample in this study amounted to 29 women with endometriosis and 21 controls.

Doing anamnesis towards mothers willing to participate in this study and have filled the approval, noted on the questionnaire sheet. Recording the identity of the patient including their name, age, parity and the first day of the last menstrual period. Before laparoscopy performed blood sample for examination of serum MMP-2. At the time of laparoscopy peritoneal fluid is taken for examination of peritoneal fluid MMP-2. Laboratory 
tests for the levels of MMP-2 serum and peritoneal fluid is carried out in the Laboratory of Microbiology Teaching Hospital Universitas Hasanuddin, Makassar.

To determine differences in the levels of MMP-2 well in the control group as well as in endometriosis used Fisher's exact test, Mann Whitney, independent $\mathrm{T}$, and Spearman association. The data were processed using SPSS 18 . Then the data are presented in tabular form with a $\mathrm{p}$ value less than 0.05 was considered significantly available.

\section{RESULTS}

Research has been conducted with cross-sectional design to determine the relationship between levels of MMP-2 in serum and peritoneal fluid with the incidence of endometriosis. The study was conducted in public service agency of Dr. Wahidin Sudirohusodo, Hospital Makassar and networking Hospital Department of Obstetrics and Gynecology, Faculty of Medicine, Universitas Hasanuddin in
Makassar began in May 2015 until May 2016.

Measurement of MMP-2 levels in serum and peritoneal fluid were conducted on 29 women with endometriosis and 21 controls (without endometriosis). Fisher test results on the characteristics of this sample showed that there were significant differences between infertility and dysmenorrhea for both groups, but other characteristics did not differ significantly ( $p>0.05)$ (Table 1).

The results of measurements of serum level of MMP-2 in both study groups showed a mean serum levels of MMP-2 of $6.03 \pm 3.26 \mathrm{ng} / \mathrm{ml}$ in the endometriosis group and $1.49 \pm 0.68 \mathrm{ng} / \mathrm{ml}$ in controls. Serum levels of the MMP-2 endometriosis group were higher than the control, and there is a significant difference $(p=0.000)$ between the two groups. The mean levels of MMP-2 were also higher peritoneal fluid in endometriosis than in controls $(1.98 \pm 1.61 \mathrm{ng} / \mathrm{ml}$ vs $0.61 \pm 0.12 \mathrm{ng} / \mathrm{ml})$, and significantly different for the two groups $(\mathrm{p}=$ 0.036) (Table 2).

Table 1. Respondent Characteristic

\begin{tabular}{|c|c|c|c|}
\hline $\begin{array}{l}\text { Respondent } \\
\text { Characteristic }\end{array}$ & $\begin{array}{c}\text { Endometriosis }(n=29) \\
n(\%)\end{array}$ & $\begin{array}{c}\text { Control }(n=21) \\
n(\%)\end{array}$ & $\mathbf{p}$ \\
\hline \multicolumn{4}{|l|}{ Age (year) } \\
\hline $20-35$ & $24(82.8)$ & $14(66.7)$ & 0.189 \\
\hline $36-45$ & $5(17.2)$ & 7 (33.3) & \\
\hline \multicolumn{4}{|l|}{ Marital status } \\
\hline Married & $26(89.7)$ & $17(81.0)$ & 0.434 \\
\hline Not married & $3(10.3)$ & $4(19.0)$ & \\
\hline \multicolumn{4}{|l|}{ Body Mass Index $\left(\mathrm{kg} / \mathrm{m}^{2}\right)$} \\
\hline Normal & $25(86.2)$ & $20(95.2)$ & 0.383 \\
\hline Overweight & $4(13.8)$ & $1(4.8)$ & \\
\hline \multicolumn{4}{|l|}{ Infertility } \\
\hline Primer & $16(55.2)$ & $8(38.1)$ & 0.009 \\
\hline Secondary & $6(20.7)$ & 0 & \\
\hline Not infertile & $7(24.1)$ & $13(61.9)$ & \\
\hline \multicolumn{4}{|l|}{ Dysmenorrhea } \\
\hline Yes & $27(93.1)$ & $3(14.3)$ & 0.000 \\
\hline No & $2(6.9)$ & $18(85.7)$ & \\
\hline \multicolumn{4}{|l|}{ Contraception } \\
\hline Yes & $3(10.3)$ & $7(33.3)$ & 0.073 \\
\hline No & $26(89.7)$ & $14(66.7)$ & \\
\hline
\end{tabular}


Table 2. MMP-2 Level in the Study Sample

\begin{tabular}{lcccc}
\hline \hline \multicolumn{1}{c}{ Sample } & $\begin{array}{c}\text { MMP-2 serum level } \\
\text { (Mean } \pm \text { DS } \mathbf{~ n g} / \mathbf{m l})\end{array}$ & $\mathbf{p}^{*}$ & $\begin{array}{c}\text { MMP-2 peritoneal fluid level } \\
\text { (Mean } \pm \text { DS } \mathbf{n g} / \mathbf{m l} \text { ) }\end{array}$ & $\mathbf{p}^{* *}$ \\
\hline Endometriosis $(\mathbf{n = 2 9 )}$ & $6.03 \pm 3.26$ & & $1.98 \pm 1.61$ & 0.036 \\
Control (n=21) & $1.49 \pm 0.68$ & 0.000 & $0.61 \pm 0.12$ \\
\hline \hline *Independent T-test & & &
\end{tabular}

**Mann-Whitney test

Table 3. MMP-2 Level in Endometriosis Stage

\begin{tabular}{cccccc}
\hline \hline $\begin{array}{c}\text { Endometrosis } \\
\text { Stage }\end{array}$ & $\mathbf{n}$ & $\begin{array}{c}\text { MMP-2 serum level } \\
\text { (Mean } \pm \text { DS } \mathbf{~ n g} / \mathbf{m l})\end{array}$ & $\mathbf{p}^{*}$ & $\begin{array}{c}\text { MMP-2 peritoneal fluid level } \\
\text { (Mean } \pm \text { DS } \mathbf{~ n g} / \mathbf{m l})\end{array}$ & $\mathbf{p}^{* *}$ \\
\hline I-II & 10 & $3.35 \pm 1.41$ & & $1.17 \pm 1.01$ & 0.119 \\
III-IV & 19 & $7.45 \pm 3.06$ & 0.000 & $2.41 \pm 1.72$ & \\
\hline
\end{tabular}

*Independent T-test

**Mann-Whitney test

The levels of MMP-2 on the stage of endometriosis showed the average serum levels of MMP-2 in stage I-II, $3.35 \pm 1.41 \mathrm{ng} / \mathrm{ml}$ and $7.45 \pm 3.06 \mathrm{ng} / \mathrm{ml}$ in stage III-IV. The mean serum levels of MMP-2 in stage III-IV is higher than stage I-II, and there is a significant difference between the two stages $(p=0.000)$. In peritoneal fluid, the mean levels of MMP-2 did not differ significantly between the two stages endometriosis' ( $p>0.05$ ) (Table 3).

Association test results showed there is a strong relationship and meaning between the levels of MMP-2 serum and endometriosis $(r=0.874$; $\mathrm{p}=0.000$ ), as well as the levels of MMP-2 peritoneal fluid and endometriosis $(r=0.383$; $\mathrm{p}=0.006$ ) (Table 4).

Table 4. The Association between MMP-2 dan Endometriosis Test Result

\begin{tabular}{lcc}
\hline \hline \multicolumn{1}{c}{ MMP-2 Level } & \multicolumn{2}{c}{ Endometriosis } \\
& $\mathbf{r}$ & $\mathbf{p}$ \\
\hline Serum & 0.874 & 0.000 \\
Peritoneal fluid & 0.383 & 0.006 \\
\hline \hline
\end{tabular}

\section{DISCUSSION}

This study shows that infertility and dysmenorrheal have an effect on endometriosis than age, marital status, BMI and contraception. Endometriosis affects $10 \%$ of women of reproductive age. Clinical symptoms are dysmenorrhea, dyspareunia and pelvic pain, making women's health worsens. Patients with endometriosis often accompanied by symptoms of dysmenorrhea and infertility complaint. The complaint is the primary reason the patient to see a doctor.

Research proves infertility due to endometriosis also increased. Hadisaputra Research found that infertility is closely related to endometriosis. Approximately $20-40 \%$ of infertile women have endometriosis. The overall prevalence of patients with endometriosis in infertile women is higher compared with fertile women. In moderate to severe endometriosis, a higher ratio of infertile patients than fertile patients. 3,10

The average age of diagnosis of endometriosis is between 25 to 35 years. ${ }^{1}$ As shown in this study, the most established was in the age range of 20-35 years. Another study by Abdullah and Manuaba found that the mean age for each case is 32 years old and 34 years old. Although the onset can occur during adolescence, detection is often done too late. Peak prevalence of endometriosis is found, at age 40 , but the risk of a woman suffering from endometriosis is 30-34 years ( $R R=2.1), 35-39$ years $(R R=4.4)$ and $40-44$ years $(R R=6.1)$ at the age range $25-29$ years. ${ }^{2,5}$ Increasing age in women affects fecundity and lowers fertility through distortion of adnexal anatomy and overproduction of prostaglandins, metalloproteinases, cytokines and chemokines cause chronic inflammation that disrupts ovarian function, tubal or endometrial so that an interruption in the process of folliculogenesis, fertilisation or implantation. ${ }^{1,10}$ 
Although some studies suggest that obesity is associated with the incidence of endometriosis but in this study only obtained five patients with a BMI> 25. In the study by Manuaba in Makassar found that normal body mass index was also obtained in most cases of endometriosis. ${ }^{5}$

Research by Vercellini et al. showed that there is decreased in the incidence risk of endometriosis in women who are new to the contraceptive pills but increased in women who had used the contraceptive pills. ${ }^{11}$ Research by Chapron et al. shows there is no relationship between the new user to use contraceptive pills with endometriosis. This study also indicates that the history of the use of contraceptive pills for primary dysmenorrhea related diagnosis endometriosis surgery at a later date, especially on deep infiltrating endometriosis. However, this does not mean that the use of contraceptive pills increases the risk of development of endometriosis. Contraceptive pill usage history can serve as a marker for women with endometriosis and deep infiltrating endometriosis while IUD use of the user's current (0-12 months) than former users (49-72 months), will increase the risk of endometriosis in former users. ${ }^{12}$ Other research by Rambulangi et al., shows the levels of MMP-2 serum and peritoneal fluid of women endometriosis is higher than the control. In this study, also obtained the levels of MMP-2 in serum and peritoneal higher in endometriosis than in controls. ${ }^{13}$

Elevated levels of MMP-2 allegedly due to the stimulation by inflammatory factors and activation MT1 MMP. This is supported by several studies showing an increase in MMP-2 along with some marker that is associated with inflammation and angiogenesis such as IL- 6 , TGF- $\beta$, TNF- $\alpha$, MIF and VEGF. ${ }^{14}$ This study also shows the levels of MMP-2 serum and peritoneal fluid of endometriosis is higher in women with stage III-IV than stage I-II, although the peritoneal fluid did not differ significantly. Association test results showed there is a strong association between high levels of MMP-2 serum and peritoneal fluid with endometriosis that may indicate the involvement of MMP-2 in the pathogenesis of endometriosis. The results are consistent with research Malvezzi et al,, also found elevated levels of MMP-2 serum of infertile women with stage III-IV higher than stage I-II. ${ }^{15}$
Pathogenesis of endometriosis regarding attachment scheme-aggression-angiogenesis (AAA) has been accepted. In this process, the role of MMP uncontested. MMP can degrade collagen and extracellular matrix components. The formation of the ectopic endometrial tissue is mediated by factors that facilitate adhesion to the peritoneal cavity, cell growth, increased aromatase activity, angiogenic, neurogenic/lymphogenic factors, and reinforced by the activity of MMP. MMP-2 plays an important role in the adhesion and proliferation of loose menstrual tissue as the pathogenesis of endometriosis. Increased circulation of MMP-2 in patients with severe pelvic endometriosis through the mechanism of major tissue remodeling happened due to disease progression, as a result of increased activity of MMP-2 systemic and local, as well as the high activity of ectopic aromatase tissues can increase the production of MMP-2, which can facilitate the invasion and progression of the disease, so that MMP-2 correlated with increasing degrees of endometriosis. ${ }^{15}$

\section{CONCLUSIONS}

The researchers concluded that there is a significant increase in the levels of both- 2 serum and peritoneal fluid in patients with endometriosis compared to women who did not suffer from endometriosis. Also found the levels of MMP-2 were higher in severe endometriosis compared with mild endometriosis, but the peritoneal fluid has not found significant differences. The levels of MMP-2 serum or peritoneal fluid is significantly correlated with the incidence of endometriosis.

\section{RECOMMENDATIONS}

Researchers suggested that to do further study on MMP-2 and other endometriosis markers in determining the diagnosis and therapy development of endometriosis.

\section{REFERENCES}

1. Fritz \& Speroff. Endometriosis in Clinical Gynecologic Endocrinology and Infertility. $8^{\text {th }}$ ed. Philadelphia: Lippincott Williams \& Wilkins, 2011: 1221-48.

2. Abdullah N. Analisis Polimorfisme Gen Vascular Endothelial Growth Factor (VEGF) pada Endometriosis. Program Pascasarjana. Disertasi. Makassar: Universitas Hasanuddin, 2008. 
3. Hadisaputra W. Kombinasi Petanda Biologis (IL-6, TNF- $\alpha$, MMP-2, VEGF) dan Gejala Serta Tanda Klinis Sebagai Model Prediktor Diagnosis Endometriosis Perempuan Masa Reproduksi. Program Pascasarjana. Disertasi. Jakarta: Universitas Indonesia, 2012.

4. Baziad A. Endometriosis pada Endokrinologi Ginekologi. Jakarta: Media Aesculapius Fakultas Kedokteran Universitas Indonesia, 2008; 250: 270-1.

5. Manuaba F. Kontribusi Endoglin pada Endometriosis : Analisis terhadap Kadar Endoglin dan Polimorfisme Gen Endoglin. Program Pasca Sarjana. Disertasi. Makassar: Universitas Hasanuddin. 2012.

6. Aresu L, Benali S, Elena M. The Role of Inflammation and Matrix Metalloproteinases in Equine Endometriosis, J Vet Sci, 2012; 13(2): 171-7.

7. Salata IM. Gelatinase A (MMP-2), Gelatinase B (MMP-9), and Their Inhibitors (TIMO 1, TIMP 2) in Serum of Women with Endometriosis: Significant Association between MMP-2, MMP-9 and Their Inhibitors without Difference in Levels of Matrix Metalloproteinase and Tissue Inhibitors of Metalloproteinases in Relation to the Severity of Endometriosis. Gynecol Endocrinol, 2008; 24(6): 326-30.

8. Weigel MT, et al. Differential Expression of MMP-2, MMP-9 and PCNA in Endometriosis and Endometrial Carcinoma. Eur J Obstet Gynecol Reprod Biol, 2012; 160: 74-8.
9. Jana S. Curcumin Delays Endometriosis Development by Inhibiting MMP-2 activity. Ind J Biochemis Biophysics, 2012; 49: 342-8.

10. Carvalho LF. From Conception to Birth : How Endometriosis Effects the Development of Each Stage of Reproductive Life. Minerva Gynecol, 2013; 65: 181-98.

11. Vercellini P. Oral Contraceptives and Risk of Endometriosis: A Systematic Review and Meta-Analysis. Hum Reprod Update, 2012; 17: 159-70.

12. Chapron C, Souza C, Borghese B, Lafay-Pillet M, Santulli $P$, Bijaoui G, et al. Oral Contraceptives and Endometriosis : The Past Use of Oral Contraceptives for Treating Severe Primary Dysmenorrhea is Associated with Endometriosis, Especially Deep Infiltrating Endometriosis. Hum Reprod, 2011; 26(8): 2028-35.

13. Rambulangi S. The Balance of Matrix Metalloproteinase-2 (MMP-2) and Tissue Inhibitor of Matrix Metalloproteinase2 (TIMP-2) on Severe Endometriosis. J Gynecol Obstet, 2015; 3(6): 111-4.

14. Gupta S. Serum and Peritoneal Abnormalities in Endometriosis: Potential Use as Diagnostic Markers. Minerva Gynecol, 2006; 58(6): 527-51.

15. Malvezzi H. Increased Circulating MMP-2 Levels in Infertile Patients with Moderate and Severe Pelvic Endometriosis. Reprod Sci, 2013; 20(5): 557-62. 